\title{
Adi Gazdar, MD: one of the founders of the molecular pathology of cancer, a great scientist and a great man
}

\author{
John D. Minna \\ Hamon Center for Therapeutic Oncology Research, Department of Internal Medicine and Pharmacology, Simmons Comprehensive Cancer Center, \\ University of Texas Southwestern Medical Center, Dallas, TX, USA \\ Correspondence to: John D. Minna, MD. Hamon Center for Therapeutic Oncology Research, Department of Internal Medicine and Pharmacology, \\ Simmons Comprehensive Cancer Center, University of Texas Southwestern Medical Center, Dallas, TX 75893, USA. \\ Email: john.minna@utsouthwestern.edu.
}

Submitted Nov 27, 2019. Accepted for publication Nov 27, 2019.

doi: $10.21037 /$ tlcr.2019.12.03

View this article at: http://dx.doi.org/10.21037/tlcr.2019.12.03

Adi Gazdar, MD, a true giant in the field of lung cancer research, passed away aged 81 on December 29, 2018. Dr. Gazdar held the W. Ray Wallace Distinguished Chair in Molecular Pathology Research and was Professor of Pathology at the Hamon Center for Therapeutic Oncology Research and Department of Pathology at the University of Texas Southwestern Medical Center in Dallas, TX. Adi Gazdar was one of the first true "molecular pathologists" of lung cancer and help leaded the development of this area around the world through is publications, collaborations, and mentoring activities. He is survived by his wife of 49 years, Celia Gazdar.

Dr. Gazdar had medical training at Guy's Hospital at the University of London and a pathology residence at the Brigham and Women's Hospital in Boston before coming to the National Cancer Institute. From 1969 until 1975 he was head of the NCI's Tumor Cell Biology Section where he studied tumor-causing retroviruses including one named after him "the Gazdar sarcoma virus" (Gz-MSV). It was during this period I met Adi through a collaboration we had studying the somatic cell genetics of murine retroviruses. In 1975 when Dr. Vincent T. DeVita gave me the opportunity to lead the NCI-Veterans Medical Oncology Branch at the Washington, DC VA Medical Center (VAMC), Adi was my first faculty recruit. In accepting my offer, it is important to note he left a well-established, well-recognized position in the NCI intra-mural virology program to join our "start up" NCI medical oncology effort at the VAMC. Of course, as part of this start up Adi and I were able to convince Paul Bunn, Dan Ihde and Desmond Carney to join us in this fledgling effort. Since lung cancer was a prominent disease of veterans, Adi and I made the key decision to switch our research efforts from somatic cell genetics and tumor viruses to the study of lung cancer molecular and cellular biology. While, this seems an obvious thing to do now, believe me, Adi and I had plenty of advice to the contrary, and I am eternally grateful for his willingness to "roll the dice" and completely change his research focus to lung cancer, which we were seeing and treating in the clinic daily. As part of this Adi and I were equally fortunate to have two investigators of world-class stature at the VAMC-Dr. Mary Matthews, Professor of Pathology, and Dr. Martin Cohen, Professor of Medicine and lung cancer clinical investigator extraordinaire. These, two incredibly kind, generous, and knowledgable professionals guided Adi and me, and the rest of your young senior staff as we took our first steps on the path for studying lung cancer. In 1981 Dr. DeVita moved the NCI-VA Medical Oncology Branch to the National Naval Medical Center in Bethesda, MD, to form the NCI-Navy Medical Oncology Branch, which lasted until 1991. We were joined there by other young investigators who would become world leaders in lung cancer research Drs. Bruce Johnson, James Mulshine, Barnett Kramer, Edward Sausville, James Battey, and world-class radiation oncologist Eli Glatstein, and thoracic surgeons Harvey Pass and Jack Roth. In 1991, I was again fortunate when Adi agree to come with me from the NCI to the University of Texas Southwestern Medical Center (UTSW) in Dallas, TX_another "leap of faith" for a very established NCI intra-mural investigator. At UTSW we had a great 27 years working together studying cancer 
biology with a special emphasis on lung cancer. During all of this period (1975-2018) one could not have had a better scientific friend or colleague than Adi, and the vast majority of the papers we published were joint efforts. Besides his well-recognized work in all types of lung cancer (nonsmall cell and small cell lung cancer), Adi made important contributions to the study of preneoplasia, mesotheliomas, endocrine tumors besides lung cancer, lymphomas, human retroviruses, ovarian and breast cancer-all of which are documented by multiple peer reviewed scientific papers. While Adi was member of several cancer scientific societies, he had a great affection and lifetime commitment to the International Association for the Study of Lung Cancer (IASLC). He served on its executive board, played key roles on advisory committees, particularly in pathology, was very proud of his Mary J. Matthews Pathology/ Translational Research Award for scientific achievements in thoracic pathology research, and in 2015, with a generous donation with his wife Celia, they established the IASLC Adi Gazdar Lectureship Award for Translational Research. Adi's research on lung cancer, mesothelioma, breast cancer, ovarian cancer, T cell lymphomas and human retroviruses are all well documented in the scientific literature in over 700 peer reviewed publications, with 88,000 citations and an "H-index" of 147 indicating he was one of the most highly cited biomedical research scientists in the world. However, here I want to highlight the traits that Adi brought to his life and work and which inspired so many of the physicians and scientists he worked, collaborated with and taught.

\section{Sharing of resources for cancer research}

One of the things that Adi was most proud of is the creation of the large panel of patient derived human lung cancer cell lines at the NCI and UTSW, which serve as "preclinical" models for the study of lung cancer by scientists around the world. While Adi and I published a lot of papers studying and using these patient derived cell line models, Adi really emphasized their true value would come from sharing them with investigators around the world which would allow validation on any experimental findings in lung cancer by multiple labs. In addition, he stressed that the wide distribution of these lines would stimulate and "democratize" lung cancer research by many investigators.

\section{Morphologic pathology based study of cancer}

From the very first, beginning with his long working relationship with Dr. Mary Matthews, Adi loved to review slides from our patients with non-pathology clinicians, especially our medical oncology fellows in training. As part of this, he would point out not only the pathology features of the tumor, but also those of the microenvironment and any preneoplastic aspects, and also provide a discussion about where "all of these parts came from" during embryology and development. Looking at a slide with Adi was not only enlightening clinically, but provided a refresher course in biology. Anyone who has heard one of Adi's scientific lectures was always impressed by the impeccable quality of the histology and cytology images he would show as part of the science. Of course, when any of us "needed" such a slide for our lecture, or a figure for a grant panel, we immediately went to Adi. Recently, computational biology with artificial intelligence analyses of large image files of tumors has become an important topic. It would not surprise anyone to know, that Adi spent hours with computational biologists, painstakingly going over the electronic image databases to make sure the images were of the highest quality and the appropriate areas selected for analyses in these new studies.

\section{Molecular applications to pathology and the study of preneoplasia}

Adi participated and led some of the first research on the molecular analyses of human tumors. In fact, I think it is fair to say he was one of the founders of the molecular pathology of lung cancer. His work included identification of some of the first detailed studies on promoter methylation as a mechanism of inactivating the expression of tumor suppressor genes, and also as markers of preneoplasia. These were closely tied with tumor micro-dissection studies (led by his fellow at the time Dr. Ignacio Wistuba) on loss of tumor suppressor gene alleles. These studies, demonstrated that, not only tumors had undergone allele loss ("loss of heterozygosity") but there were thousands of clones of preneoplasia with such loss that could be found in smoking damaged lung epithelium, including samples from persons who had stopped smoking decades before demonstrating the persistence of such genetic changes.

\section{Intellectual curiosity and hypothesis formation}

All of us who interacted with Adi on a regular basis were reminded of his great intellectual curiosity about how things worked. He loved studying problems in cell biology and 
cancer. While he brought his perspective as a pathologist to these problems, he loved searching the literature for related publications to whatever studies his lab was working on. Many times over the years, I saw him delve into literature searches (in "the old days" this was in the library, and then on his computer) where I would not hear anything from him for weeks at a time, and then he would come in and tell me about his complete analyses of the world's literature on his current topic of interest. These were terrific opportunities for me to learn as well and all of us welcomed Adi's impromptu lectures on the current subject that had sparked his interest. As part of this, Adi always, and I mean always, would form a "model" or hypothesis about this all meant. While, he often was many steps ahead of what he could show in the lab, in his head he had already pieced together his working model of what he thought was happening. Of course, these models could be wrong, but I saw they served a very important organizing feature for his research work. Of equal importance they gave those who were working with him a structure to work with, and from the very first, an idea of why what they were working on was important.

\section{Mentorship-teaching}

Adi loved to teach, students, post-doctoral fellows, collaborators, other faculty. As part of this he loved playing the role of mentor. Because the conference room for the "Works in Progress" meetings for each of the Hamon Center labs is right off my office, on a weekly basis I would hear Adi teaching his lab members during his regular lab research meetings. While he gave tremendous lectures on pathology (and was an important part of medical student teaching at UTSW), he really liked "teaching" about the project his group was currently working on. He would emphasize why the topic was important, the "hows and whys" of the approach he was using to tackle the problem, including which standard and new techniques he was using. As part of this he would always relate his work to all the other stuff going on in the field previously and at the same time. He always did this with a "light" hand.- and never "showing off." At the end of these "teaching" sessions we had all invariably learned about an important problem and usually about a new field as well. Of course his mentorship extended many years after a postdoctoral fellow had left the lab. He enjoyed keeping in contact with the large number of prior fellows he had trained and always took great pride in their later successful careers.

\section{World-wide scientific collaborations}

Looking at Adi's bibliography it is obvious that he had a worldwide network of collaborations. Of course he had many collaborators in the USA and often these were either part of our Lung Cancer Special Program of Research Excellence (SPORE, P50CA080907) or other multiinvestigator grants and projects such those of the NCI's Early Detection Research Network (EDRN). He was adept at juggling multiple collaborations at the same time. As part of this he loved keeping in close contact with his collaborators by phone and email. He particularly enjoyed collaborating with young investigators at other institutions and wanted to make sure they got major credit with any publications. Throughout all of this, he was scrupulous about keeping other people's data "private" and honoring his commitments. We talked about science daily for over 40 years, and he was always excited about his latest "finding" of a collaborator that brought in new perspectives and approaches to research. He felt that was how he "learned" new things.

\section{Love of travel, athletics, and history}

Adi loved to travel and he and I had many "arguments" about him traveling "too much" since I was the one who administratively had to approve his travel. I don't know how many countries he went to on his scientific expeditions, but there were a lot. As one example, we were right in the middle of a large NCI grant preparation and I saw that he was going to Europe. I told the administrative staff how upset I was, and one of them timidly said- "well I guess you also need to know he is also going from Europe to China!" Adi would just look sheepishly down and say, "well I promised these people I would visit and give them a lecture." What could one say? In his earlier life Adi was a tournament level squash player and having played many sets of tennis with him, I can vouch that he was a far above average tennis player. Later in life he became a super competitive racquetball player. In addition, he would routinely walk up many flights of stairs to our offices at the NCI or UTSW as part of his "physical fitness" program. Integrated with his travel, was his voracious reading of history. He loved it all, modern, ancient, American, European, and Asian. $\mathrm{He}$ particularly would read about the history of the various countries he was visiting and always came back from his trips as a font of historical knowledge about various countries. 


\section{Humor}

Adi loved a good joke, but even more he loved telling a story about some ridiculous event he had witnessed. In addition, he loved adding humor to his slides. These sometimes got him in "trouble" with more "politically correct" audiences but he just forged ahead. While there are countless jokes he played on me, I remember going into his office, which as many people know, would consist of a desk completely covered several feet high in books and paper and my yelling- " The next day, a picture appeared on his office door showing Einstein's office the day he died (which was of course a desk/table piled high with disordered papers). His humor was usually wry, and I also remember at the Navy Medical Center at the end of one day, I asked how he was doing as we were leaving the building, and he casually said "not bad, actually kind of interesting. A guy came into my office (pathologist type office) pulled up his pant leg, showed me a bullet wound, and said, 'Doc could you fix this up for me?"'

\section{Speaking "truth to power"}

One of the most important things to know about Adi Gazdar was how honorable a person he was in all aspects. This was true in scientific things and all aspects of life. If you asked Adi for his opinion on a difficult situation or topic he always gave a straight answer. In addition, if he thought someone important was doing something that was not right, political consequences "be damned" Adi would go up and tell them what he thought. This was also true in various scientific "debates" he found himself in. If he felt the other person had made a better case than his, he would admit it directly and give the person credit. As you can imagine, because of these qualities, we always listened closely to Adi's thoughts and advice on sensitive issues.

All of us who had the honor of knowing and working with Professor Adi Gazdar will miss him. He was a remarkable scientist, colleague, friend, and a great human being.

\section{Acknowledgments}

Funding: None.

\section{Footnote}

Conflicts of Interest: JDM serves as the unpaid editorial board member of TLCR. JDM receives royalties from the NIH and UTSW for distribution of cell lines created with AFG.

Ethical Statement: The author is accountable for all aspects of the work in ensuring that questions related to the accuracy or integrity of any part of the work are appropriately investigated and resolved.

Open Access Statement: This is an Open Access article distributed in accordance with the Creative Commons Attribution-NonCommercial-NoDerivs 4.0 International License (CC BY-NC-ND 4.0), which permits the noncommercial replication and distribution of the article with the strict proviso that no changes or edits are made and the original work is properly cited (including links to both the formal publication through the relevant DOI and the license). See: https://creativecommons.org/licenses/by-ncnd/4.0/.
Cite this article as: Minna JD. Adi Gazdar, MD: one of the founders of the molecular pathology of cancer, a great scientist and a great man. Transl Lung Cancer Res 2020;9(Suppl 1):S133S136. doi: 10.21037/tlcr.2019.12.03 